\title{
Morfoanatomia da plântula de Campomanesia xanthocarpa O. Berg. (Myrtaceae) $)^{1}$
}

\author{
Alessandra Mara Gogosz ${ }^{2}$, Nelson Luiz Cosmo ${ }^{3}$, Cleusa Bona ${ }^{2,5}$ e Luiz Antonio de Souza ${ }^{4}$
}

Recebido em 17/02/2009. Aceito em 15/09/2009

\begin{abstract}
RESUMO - (Morfoanatomia da plântula de Campomanesia xanthocarpa O. Berg. (Myrtaceae)). Campomanesia xanthocarpa (guabirobeira) é espécie arbórea, heliófita, ocorrendo desde o estado de Minas Gerais até o Rio Grande do Sul. Visando descrever a morfologia e anatomia da plântula, sementes foram coletadas e plantadas, utilizando-se vermiculita como substrato. Plântulas foram coletadas para análise morfológica desde a protrusão da radícula até a fase em que são emitidos os primeiros pares de eofilos. Para a análise anatômica foram coletadas plântulas com sete, 30 e 60 dias após a germinação. As amostras foram fixadas em glutaraldeído (1\%) + formaldeído (4\%), incluídas em historesina, seccionadas em micrótomo, e montadas de forma permanente. A plântula é epígea, fanerocotiledonar, com paracotilédones e eofilos simples, opostos. Nas plântulas com sete dias observa-se o início da formação do câmbio e as de 30 dias já apresentam crescimento secundário. O paracotilédone e o eofilo apresentam características morfoanatômicas semelhantes. O hipocótilo é o principal órgão de reserva, contendo grãos de amido, especialmente nas plântulas com sete dias. Foram registradas glândulas e células secretoras em todos os órgãos, exceto na raiz. A epiderme dos paracotilédones, eofilos e hipocótilo apresenta tricomas tectores unicelulares. Idioblastos com cristais são comuns no mesofilo do paracotilédone e do eofilo.
\end{abstract}

Palavras-chave: estágios de desenvolvimento, morfologia, anatomia, gabiroba

\begin{abstract}
Morphology and anatomy of Campomanesia xanthocarpa O. Berg. seedlings (Myrtaceae)). Campomanesia xanthocarpa ("guabirobeira") is a heliophytic tree species that occurs from Minas Gerais to Rio Grande do Sul. To describe the morphology and anatomy of the seedling, seeds were collected and planted in a vermiculite substrate. Seedlings were collected for morphological analysis from the root emergence stage to that where the first eophyll pairs emerge. For anatomical analysis, seedlings were collected 7, 30 and 60 days after germination. The samples were fixed in glutaraldehyde $(1 \%)+$ formaldehyde $(4 \%)$, embedded in historesin, sectioned by microtome, and mounted on a permanent slide. The seedling is epigeous, phanerocotylar with simple, opposite paracotyledons and eophylls. In 7-day-old seedlings, cambium formation begins and, 30 days after root emergence, the seedlings show secondary growth. The paracotyledons and eophylls have similar anatomical and morphological characteristics. The hypocotyl is the main storage body, containing starch grains, especially in 7-day-old seedlings. Glands and secretory cells occur in most organs excluding the root. The epidermis of the paracotyledons, eophylls and hypocotyl has simple, unicellular trichomes. Idioblasts with crystals are common in the mesophyll.
\end{abstract}

Key words: Developmental stages, morphology, anatomy, "gabiroba"

\section{Introdução}

Campomanesia xanthocarpa O. Berg. (guabirobeira) é uma espécie arbórea que ocorre desde o estado de Minas Gerais até o Rio Grande do Sul. Trata-se de uma planta heliófila, seletiva higrófila até mesófila, sendo bastante frequente na Floresta Ombrófila Mista, especialmente nos solos úmidos das formações aluviais, nos capões e em áreas mais abertas das florestas secundárias (Reitz 1983). Os frutos desta espécie, tais como de outras do mesmo gênero, são consumidos por várias espécies de pássaros e mamíferos, sendo também usados na produção de doces caseiros, sorvetes, aguardente, licores e refrescos (Vallilo et al. 2004). Além disso, C. xanthocarpa é indicada para plantios em áreas degradas e pode ser utilizada como espécie ornamental (Souza \& Lorenzi 2005).

Assim como ocorre com grande parte da flora brasileira, pouco se conhece sobre os aspectos morfológicos e anatômicos das plantas de C. xanthocarpa no início do seu desenvolvimento, logo após a germinação. Tanto o comportamento germinativo da semente, quanto o desenvolvimento inicial da planta, são estágios críticos para o seu estabelecimento e, portanto, pesquisas sobre estes aspectos são muito relevantes para o conhecimento da espécie como um todo.
Nas plantas, em geral, o início da germinação ocorre com a embebição da semente, produzindo um aumento de volume e o rompimento de seus envoltórios. A radícula cresce dando origem à raiz primária, que rapidamente penetra no solo e se ramifica, passando a exercer a função de absorção. Simultaneamente, produz-se um crescimento que eleva a plúmula, colocando-a em condições de iluminação adequadas para seu desenvolvimento (Beltrati \& Paoli 2003). A fase compreendida entre a germinação consumada da semente até a formação da primeira folha ou eofilo caracteriza o estágio de plântula. Após esta fase, entre o final do desenvolvimento do primeiro eofilo na plântula até o momento em que aparecem os primeiros nomofilos, caracteriza-se o estágio de tirodendro (Souza 2003).

Os trabalhos de morfologia de plântulas têm merecido atenção há algum tempo, tanto como parte de estudos morfoanatômicos, com o objetivo de ampliar o conhecimento sobre determinada espécie ou grupo de plantas, quanto visando reconhecimento e identificação de plântulas de determinada região, dentro de um enfoque ecológico (Oliveira 1993). Diversos autores relatam que as características das plântulas frequentemente estão relacionadas com as condições ambientais de ocorrência das espécies (Vogel 1980; Wright

\footnotetext{
1 Parte da dissertação de Mestrado da primeira Autora

2 Universidade Federal do Paraná, Departamento de Botânica, Setor de Ciências Biológicas, Curitiba, PR, Brasil

3 Universidade Federal do Paraná, Departamento de Ciências Florestais, Curitiba, PR, Brasil

4 Universidade Estadual de Maringá, Departamento de Biologia, Maringá, PR, Brasil

5 Autor para correspondência: cleusabona@ufpr.br
} 
et al. 2000; Ibarra-Manríquez et al. 2001). Portanto, uma análise detalhada desta fase possibilita um entendimento da auto-ecologia e do desenvolvimento inicial das espécies nos ambientes de ocorrência natural.

Alguns trabalhos no Brasil têm contribuído para os estudos de taxonomia e ecologia a partir da análise de plântulas de espécies nativas. Kuniyoshi (1983) analisou o desenvolvimento das plântulas de várias espécies arbóreas da Floresta Ombrófila Mista, além de trazer informações sobre frutos e sementes. Nakamura \& Scatena (2009) investigaram o padrão de desenvolvimento pós-seminal em Poaceae. Plântulas de algumas espécies de Euphorbiaceae foram descritas por Oliveira \& Pereira (1987), e de leguminosas por Oliveira (2001). Ressel et al. (2004), por sua vez, abordaram os aspectos morfofuncionais das plântulas de diversos táxons de uma estação ecológica, em Minas Gerais. Também em uma abordagem ecológica, Marques \& Oliveira (2005) investigaram as características reprodutivas de espécies da planície costeira, considerando, dentre outros aspectos, os tipos morfofuncionais das plântulas.

No entanto, para algumas famílias botânicas comuns no Brasil, tal como ocorre com Myrtaceae, os trabalhos de morfologia de plântulas são muito escassos. Além disso, a maioria dos trabalhos tem se limitado às características morfológicas, sem abordar a estrutura dos diversos órgãos. A análise anatômica certamente permite uma investigação ainda mais aprofundada das espécies, tal como realizada por Souza \& Oliveira (2004), em plântulas de Tabebuia avellanedae Lar. Ex Griseb e T. chrysotricha (Mart. Ex Dc.) Standl. Além disso, trabalhos que abordam a caracterização das plantas podem servir de subsídio para a identificação da espécie no campo.

O presente trabalho teve como objetivos analisar e descrever a morfologia e a estrutura anatômica da plântula de C. xanthocarpa, considerando seu desenvolvimento e as características que possam ter importância para a taxonomia e auto-ecologia da espécie.

\section{Material e métodos}

Frutos maduros de C. xanthocarpa foram coletados de seis árvores, localizadas no município de Colombo - PR, região da Floresta Ombrófila Mista, em dezembro de 2005. Para a obtenção das sementes foi realizada a despolpa dos frutos em água corrente, com o auxílio de uma peneira. Posteriormente, as sementes foram deixadas por algumas horas sobre jornal, em local sombreado e ventilado, para a secagem.

Foram plantadas 250 sementes em bandejas plásticas, com dez centímetros de altura, contendo como substrato uma mistura em partes iguais de terra preta e vermiculita. As sementes foram mantidas sob nebulização controlada (a cada 30 minutos) em casa de vegetação, no Departamento de Botânica da Universidade Federal do Paraná (UFPR).

Para análise da morfologia foram coletadas 20 plântulas, desde a protrusão da raiz primária até o desenvolvimento dos primeiros pares de eofilos (até 60 dias de idade). A morfologia das plântulas foi ilustrada com auxílio de microscópio estereoscópico. As descrições morfológicas foram realizadas de acordo com as terminologias de Vogel (1980) e Souza (2003).

Para análise anatômica, as amostras foram fixadas em glutaraldeído (1\%) + formaldeído (4\%) (McDowell \& Trump 1976), incluídas em historesina (Leica $\left.{ }^{\circledR}\right)$, seccionadas em micrótomo de rotação, distendidas em lâminas e submetidas à coloração com azul de toluidina (O` Brien et al. 1964). Para a anatomia da raiz primária, foram realizadas secções do ápice (longitudinal) e da região a um centímetro do ápice (transversal), de plântulas com 30 dias de idade. O colo e a região mediana do hipocótilo foram amostrados em plântulas com sete e 30 dias. Na região do nó paracotiledonar foram feitos cortes seriados, em plântulas com sete dias. Para a análise dos paracotilédones, foram amostradas plântulas com 30 dias e, para os eofilos, com 60 dias, de forma a obter estes órgãos já expandidos. Para cada uma destas análises, foram amostradas cinco plântulas, tomadas aleatoriamente.

Foram também realizados cortes a mão, com navalha de aço descartável, de material fresco da raiz primária, da região do colo, da região mediana do hipocótilo e região mediana dos paracotilédones e eofilos. Esses foram submetidos a testes microquímicos com lugol (Berlyn \& Miksche 1976) para detectar amido; sudam III (Sass 1951) para detectar substâncias graxas e cloreto férrico 10\% (Johansen 1940) para detectar compostos fenólicos. As lâminas foram montadas de forma semipermanente e analisadas em microscópio fotônico no Laboratório de Botânica Estrutural, do Departamento de Botânica da UFPR. As lâminas foram analisadas e os tecidos ilustrados com auxílio de câmara clara acoplada ao microscópio fotônico, no Laboratório de Botânica Estrutural. As caracterizações anatômicas foram descritas de acordo com as terminologias de Souza (2003) e Evert (2007).

\section{Resultados}

Morfologia e desenvolvimento da plântula - A germinação de $C$. xanthocarpa é epígea e a plântula tem desenvolvimento fanerocotiledonar, com paracotilédones foliáceos, fotossintetizantes (Fig. 1A-E).

O desenvolvimento da plântula de C. xanthocarpa iniciase com a protrusão da raiz primária, a partir do rompimento da parede do diásporo, na região da micrópila (Fig. 1A). Logo nos primeiros dias (três a quatro), é possível observar a emissão de raízes secundárias na região do colo (Fig. 1B e C). Em seguida, ocorre a emergência do hipocótilo (Fig. 1B, C), inicialmente curvo, glabro, com aspecto robusto, e cor amarelada. Nesta fase também são expostos os paracotilédones, que inicialmente são bem reduzidos. Em poucos dias (dois a três), o hipocótilo torna-se ereto, livrando-se totalmente da parede do diásporo e adquire cor verde.

Após a expansão dos paracotilédones (Fig. 1D), o hipocótilo adquire aspecto lenhoso, coloração castanho-escura, e apresenta estrias longitudinais claras. O colo é bastante distinto, sendo caracterizado por uma pequena constrição na base do hipocótilo. Nesta fase, ocorre o desenvolvimento do primeiro par de eofilos, com filotaxia oposta cruzada, finalizando o estágio de plântula.

O paracotilédone e o eofilo maduros têm aspecto muito semelhante quanto à cor, textura, venação e forma do limbo. Ambos são curto-peciolados, glabros, com margem inteira e venação bem evidente, com veias laterais conectadas próximo da margem da folha, por uma série de arcos fortemente curvados. Em geral, o paracotilédone é cordiforme, com ápice agudo e base cordada, enquanto que o eofilo é elíptico, com ápice agudo a retuso e base obtusa, segundo a classificação de Hickey (1979), porém, observam-se pequenas variações neste padrão, como nota-se na figura 2 .

Anatomia da plântula - Raiz - No ápice da raiz primária, em seção longitudinal, identifica-se a coifa parenquimática, formada pelo caliptrogênio e o tecido promeristemático, este último constituído por células diminutas (Fig. 3A). Logo 


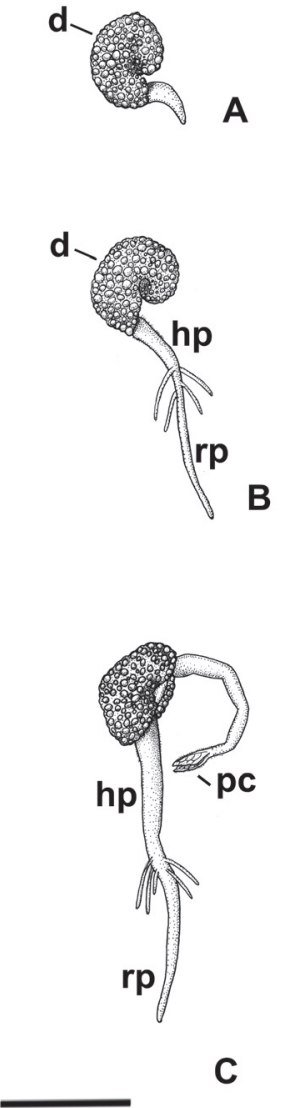

$10 \mathrm{~mm}$
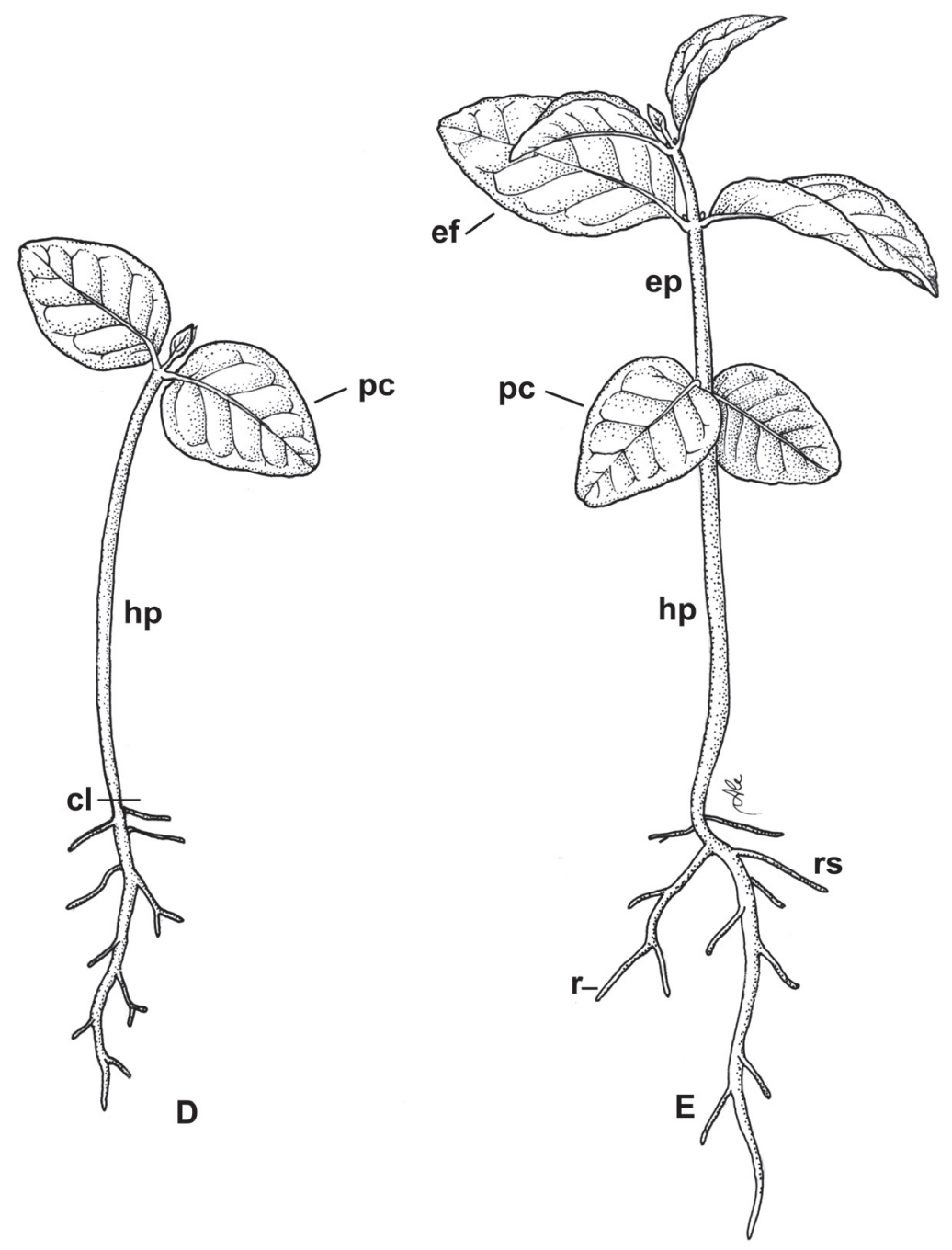

Figura 1. Desenvolvimento inicial de Campomanesia xanthocarpa O. Berg. (Myrtaceae). A. Início do desenvolvimento; B. Emissão da raiz e do hipocótilo em plântula com três dias; C. Emergência dos paracotilédones sete dias após a protrusão da raiz; D. Plântula com 30 dias, com paracotilédones expandidos e início do desenvolvimento dos eofilos; E. Tirodendro com 60 dias. (cl: colo; d: diásporo; ef: eofilo; ep: epicótilo; hp: hipocótilo; pc: paracotilédone; rp: raiz primária; rs: raiz secundária).

acima da região promeristemática distingue-se a protoderme, com pelos radiculares em formação (Fig. 3B).

Em seção transversal da raiz primária de plântulas com 30 dias, nota-se a epiderme unisseriada, com células de paredes pouco espessas. $\mathrm{O}$ córtex é formado por exoderme uniestratificada, parênquima e endoderme contendo compostos fenólicos e estrias de Caspary. O cilindro central varia de pentarco a hexarco, com metaxilema central e cordões floemáticos bem delimitados, localizados entre os polos de protoxilema. Nesta fase já há câmbio e pouco xilema secundário (Fig. 3C).

Hipocótilo - O hipocótilo (Fig. 4A-E) apresenta córtex parenquimático, com células secretoras subepidérmicas e endoderme com amiloplastídios (bainha amilífera) (Fig. 4B, D). Em seção transversal da região mediana do hipocótilo, em plântulas com sete dias, nota-se que este órgão apresenta estrutura de transição entre raiz e caule. Isto é evidente pela disposição tangencial dos elementos traqueais do xilema primário, na periferia da medula parenquimática (Fig. 4B, C). A condição exarca da raiz passa à endarca, tipicamente caulinar, apenas próximo ao nó paracotiledonar.

Em plântulas com 30 dias, diferencia-se uma camada subepidérmica de colênquima no córtex do hipocótilo. Ocorre também a instalação do câmbio e o início da formação dos tecidos vasculares secundários. Nesta fase é possível observar que o cilindro vascular é anfiflóico. Em plântulas com sete dias, no entanto, não se nota a presença de floema interno no hipocótilo, exceto em sua porção basal, próxima ao colo, indicando que sua formação se dá tardiamente em relação ao floema "externo". Nota-se ainda que o floema interno formase a partir da divisão de células meristemáticas na periferia da medula, numa fase que coincide, aproximadamente, com o início do crescimento secundário (Fig. 4D, E). 
pc
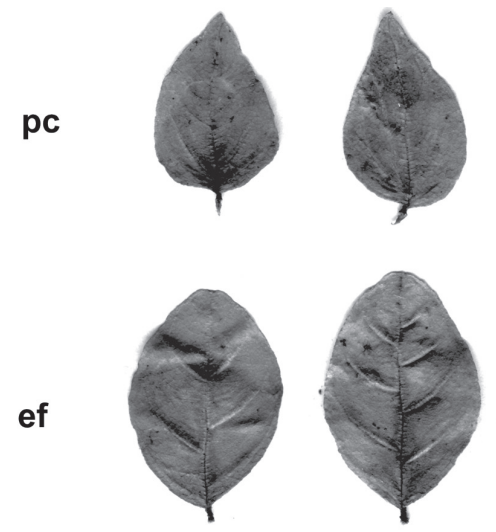

pc
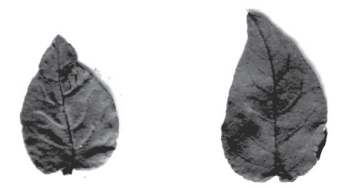

ef
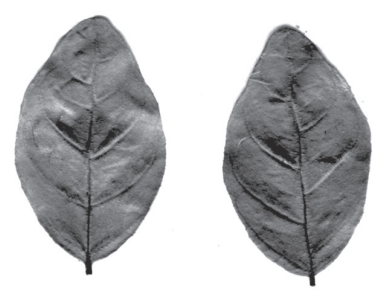

pc
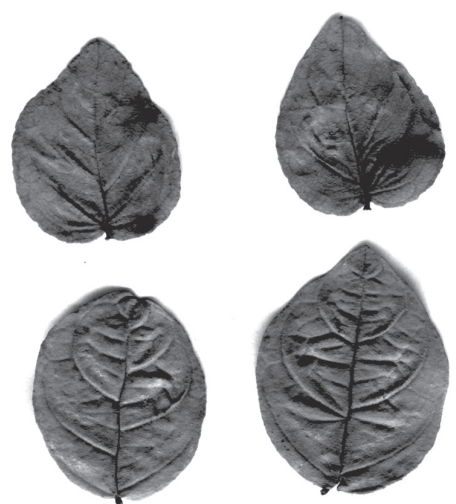
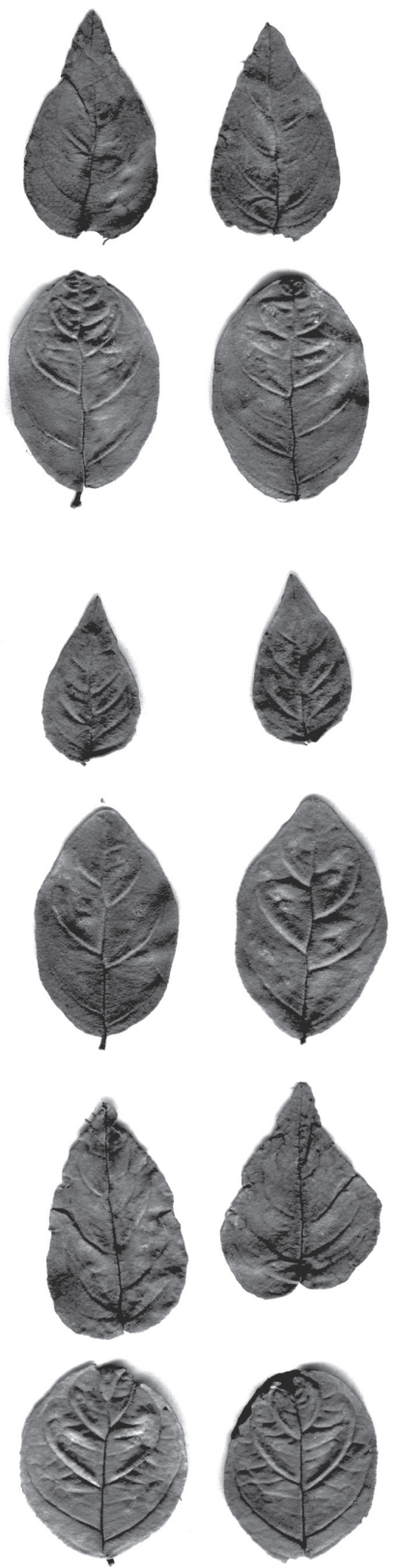
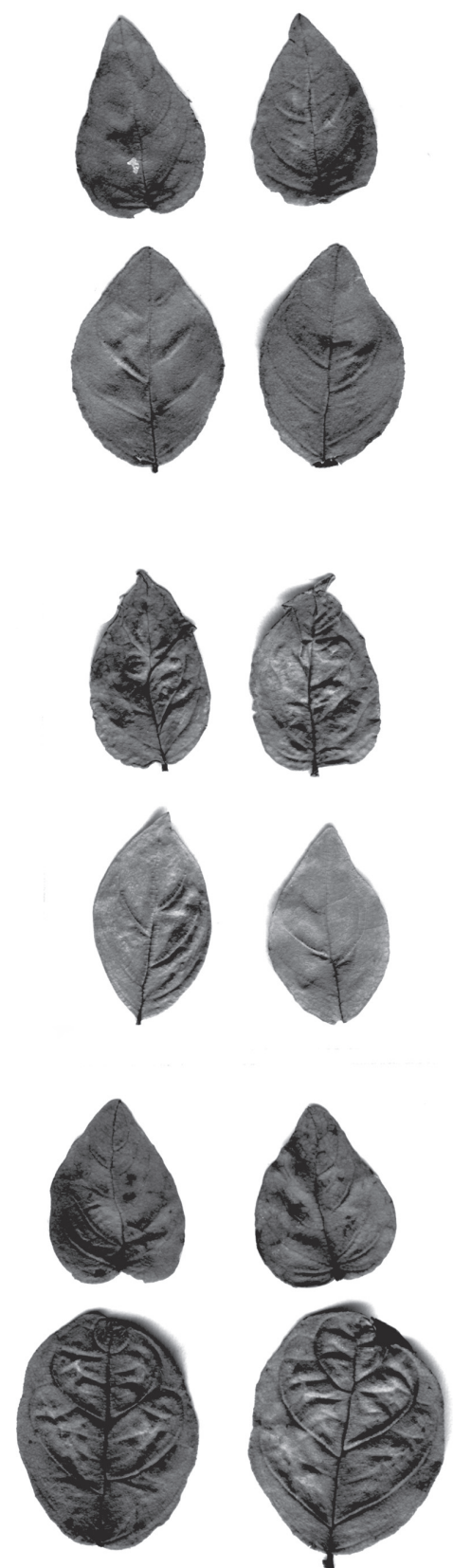

Figura 2. Variações no aspecto morfológico dos paracotilédones e eofilos maduros de Campomanesia xanthocarpa O. Berg. (Myrtaceae), (pc: paracotilédone; ef: eofilo).

Foi observada a presença de grãos de amido nas células parenquimáticas do córtex e da medula do hipocótilo, em maior quantidade nas plântulas com sete dias, quando comparadas às plântulas com 30 dias, nas quais o amido está concentrado na camada mais interna do córtex.

Nó paracotiledonar - A região do nó (Fig. 5A-E) caracterizase pela presença de um traço foliar unilacunar para cada um dos paracotilédones (Fig. 5C-D). Na axila do paracotilédone ocorre um par de estípulas, visíveis apenas sob microscópio estereoscópico (Fig. 5A, B). Estas morrem logo no início do desenvolvimento da plântula, antes mesmo da emissão dos eofilos, adquirindo coloração castanho-escura. O hipocótilo logo abaixo da região do nó paracotiledonar (Fig. 5E, F), diferente do que ocorre em sua região mediana, apresenta os polos de metaxilema e protoxilema organizados de forma endarca (Fig. 5F), típica de caule.

Paracotilédones e eofilos - Assim como ocorre com os aspectos morfológicos, o paracotilédone e eofilo maduros 


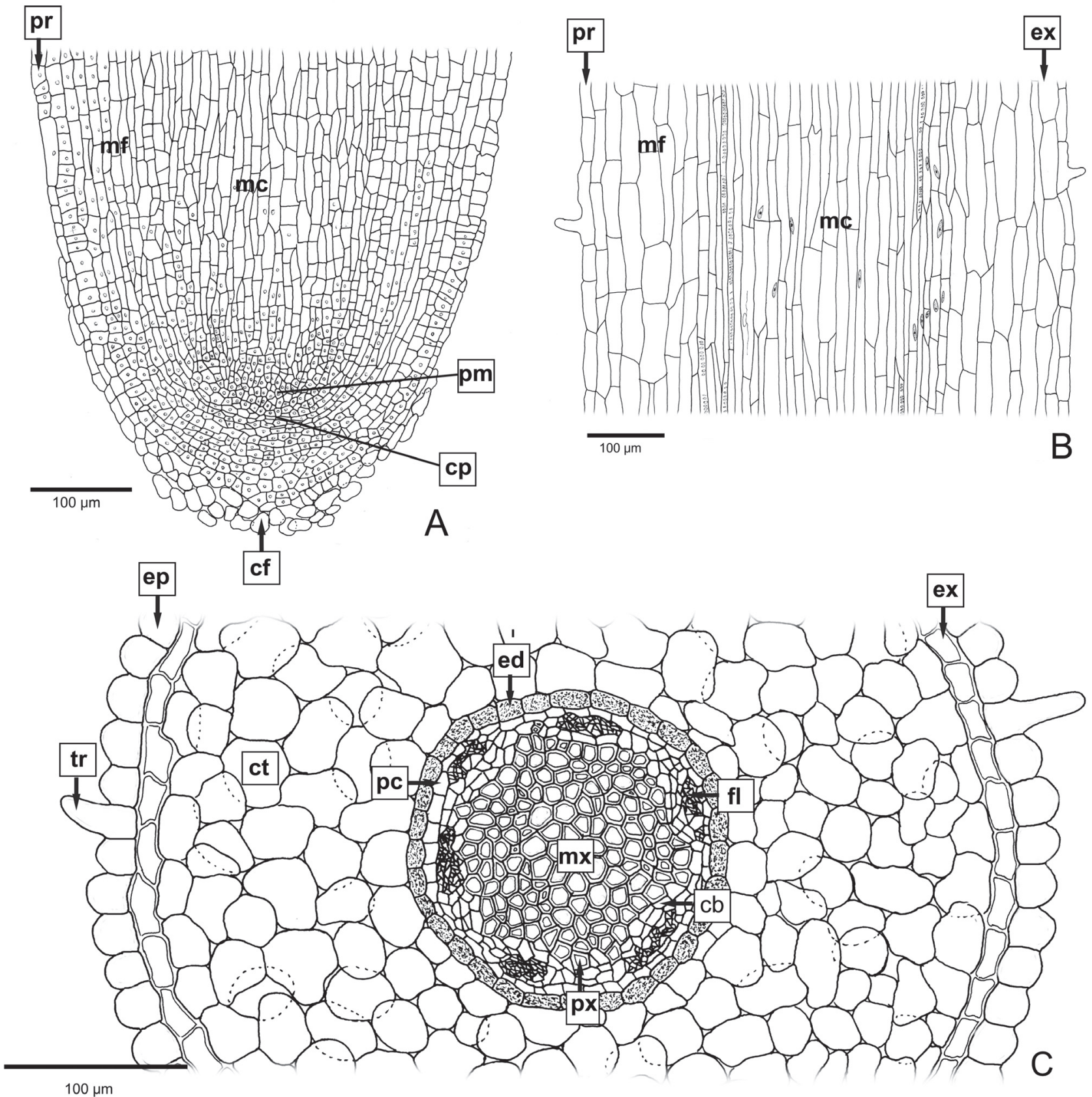

Figura 3. Anatomia da raiz de plântula de Campomanesia xanthocarpa O. Berg. (Myrtaceae). A. Seção longitudinal do ápice, em plântula com sete dias; B. Seção longitudinal na zona pilífera em plântula com sete dias; C. Seção transversal na zona pilífera em plântula com 30 dias. (cb: câmbio; cf: coifa; cp: caliptrogênio; ct: córtex; ed: endoderme; ep: epiderme; ex: exoderme; fl: floema; mc: meristema do cilindro central; mf: meristema fundamental; mx: metaxilema; pc: periciclo; pm: pró-meristema; pr: protoderme; px: protoxilema; tr: tricoma).

de C. xanthocarpa apresentam características estruturais bastante semelhantes (Fig. 6A-F). Ambos têm epiderme unisseriada, com estômatos paracíticos na face abaxial (Fig. 6E); mesofilo heterogêneo dorsiventral, composto de uma camada de parênquima paliçádico e duas a quatro de lacunoso; nervura central com colênquima em posição subepidérmica e feixe vascular concêntrico, envolto por uma bainha de esclerênquima.

Estruturas secretoras - C. xanthocarpa possui glândulas secretoras (Fig. 7A-G), abundantes em praticamente todos os órgãos, com exceção da raiz. Estas glândulas têm conteúdo lipídico, conforme verificado através do teste com Sudam III. A formação destas estruturas em C. xanthocarpa ocorre a partir da combinação de esquizogenia, em um primeiro momento, e lisigenia, na fase final do seu desenvolvimento, tratando-se, portanto de glândula esquizolisígena, conforme representado na figura 7 , na qual estão ilustradas a fase de separação das células centrais (Fig. 7D, E) e a presença de células rompidas na região periférica da cavidade, em glândula plenamente formada (Fig. 7F, G). 


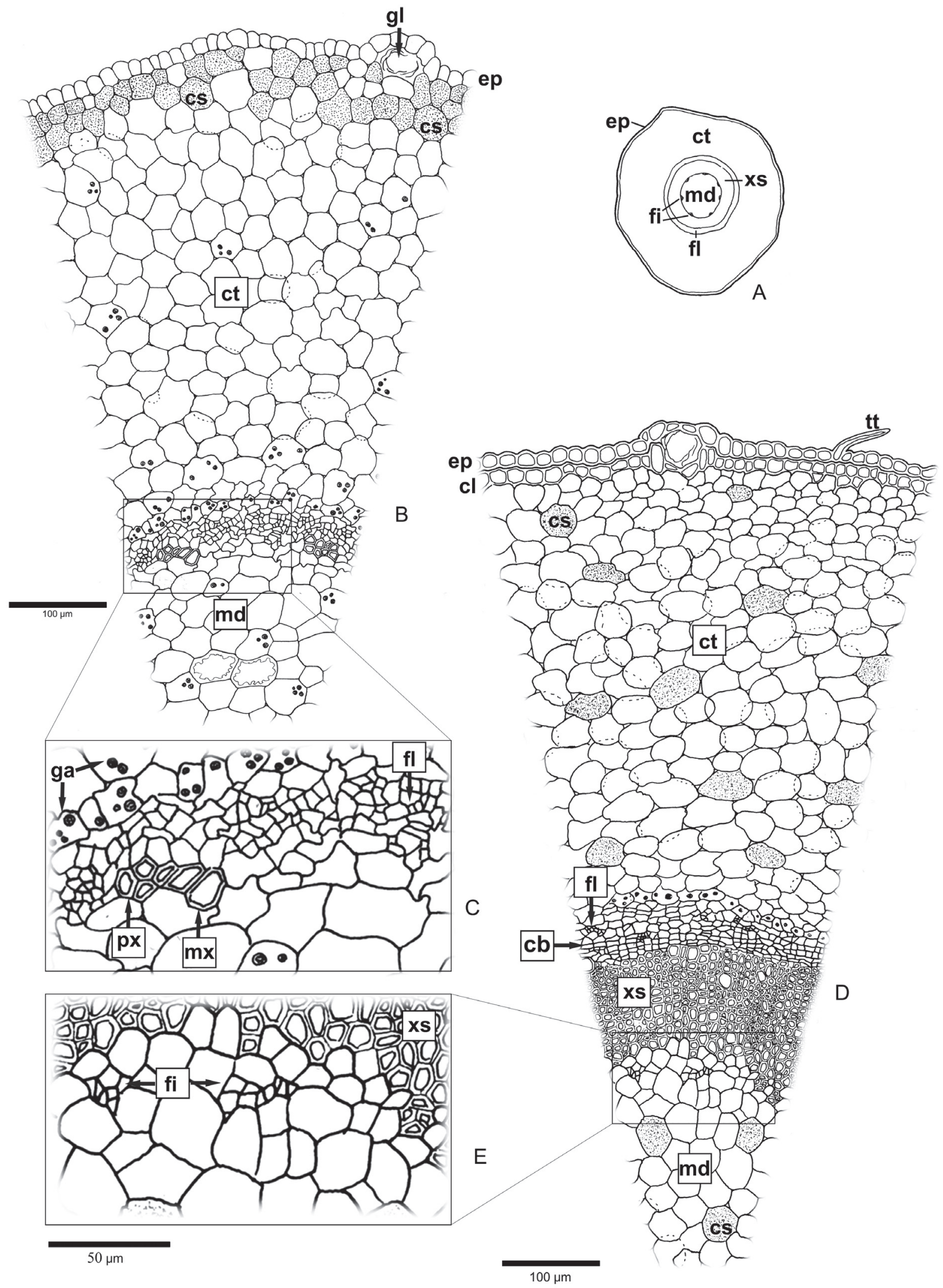

Figura 4. Região mediana do hipocótilo de Campomanesia xanthocarpa O. Berg. (Myrtaceae). A. Plântula com 30 dias; B. Plântula com sete dias; C. Detalhe do cilindro vascular; D. Plântula com 30 dias; E. Detalhe da periferia da medula (floema interno). (cb: câmbio; cl: colênquima; cs: célula secretora; ct: córtex; ep: epiderme; fl: floema; fi: floema interno; ga: grãos de amido; gl: glândula; md: medula; mx: metaxilema; px: protoxilema; tt: tricoma tector; xs: xilema secundário). 


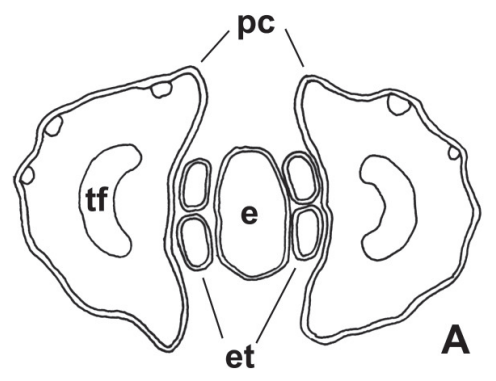

$250 \mu \mathrm{m}$
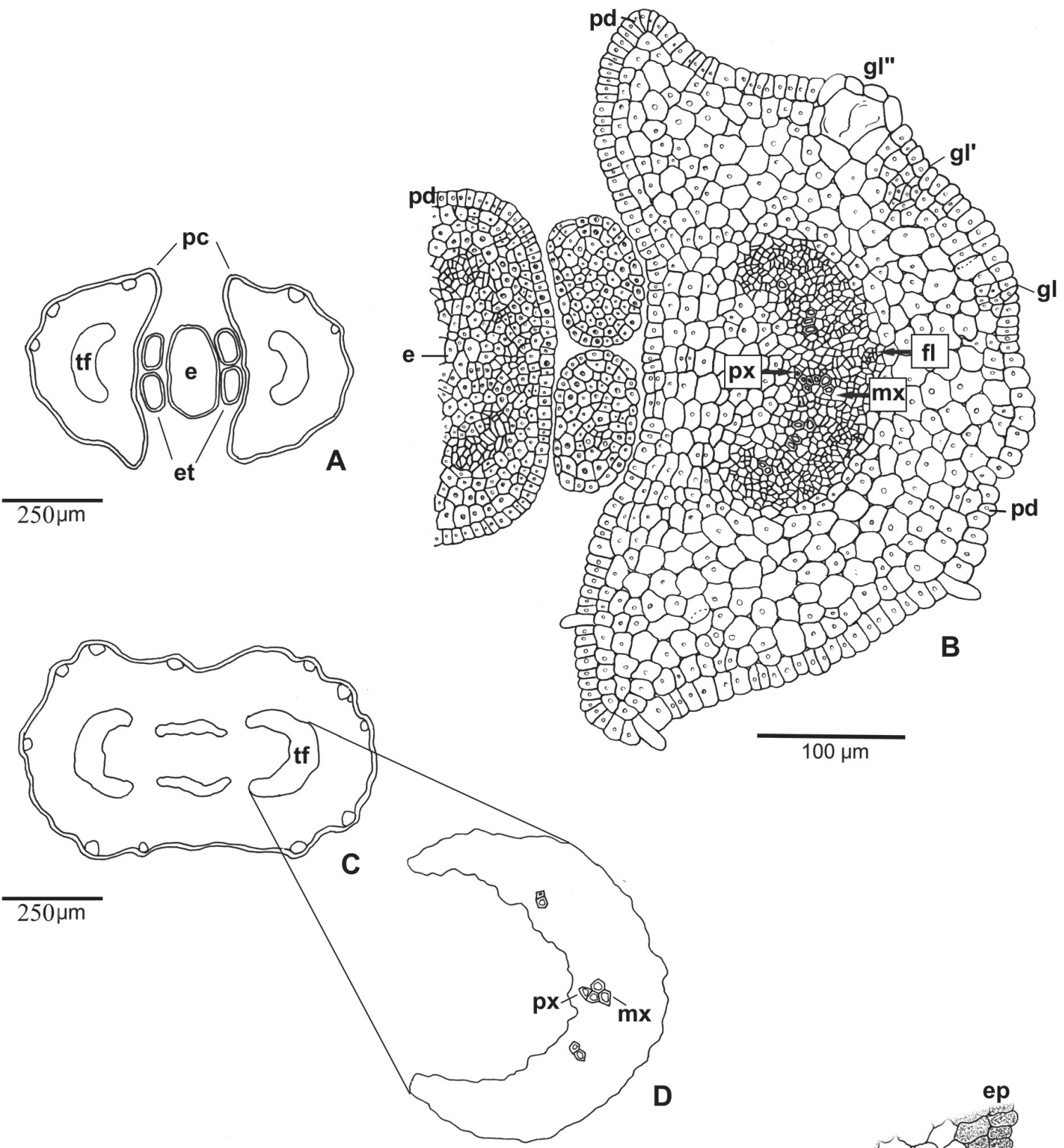

E

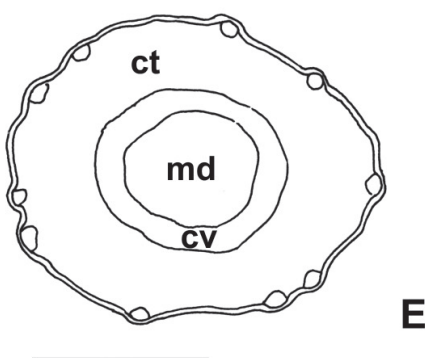

$250 \mu \mathrm{m}$

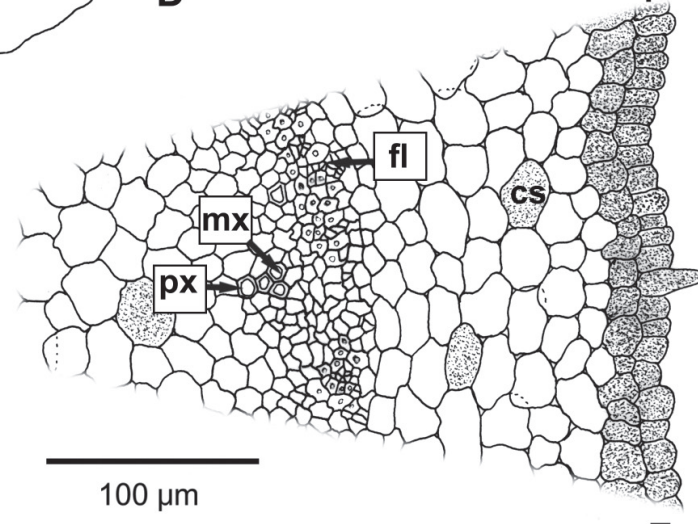

$\mathbf{F}$

Figura 5. Região do nó paracotiledonar de plântula com sete dias, de Campomanesia xanthocarpa O. Berg. (Myrtaceae). A. Região acima da inserção dos paracotilédones; B. Detalhe; C. disposição dos traços foliares no nó; D. Pólos de xilema primário no traço foliar; E. Hipocótilo abaixo do nó; F. Detalhe. (cs: célula secretora; ct: região do córtex; cv: cilindro vascular; et: estípula; e: epicótilo; ep: epiderme; fl: floema; gl, gl', gl": ontogênia da glândula secretora; md: região da medula; mx: metaxilema; pc: pecíolo; pd: protoderme; tf: traço foliar). 

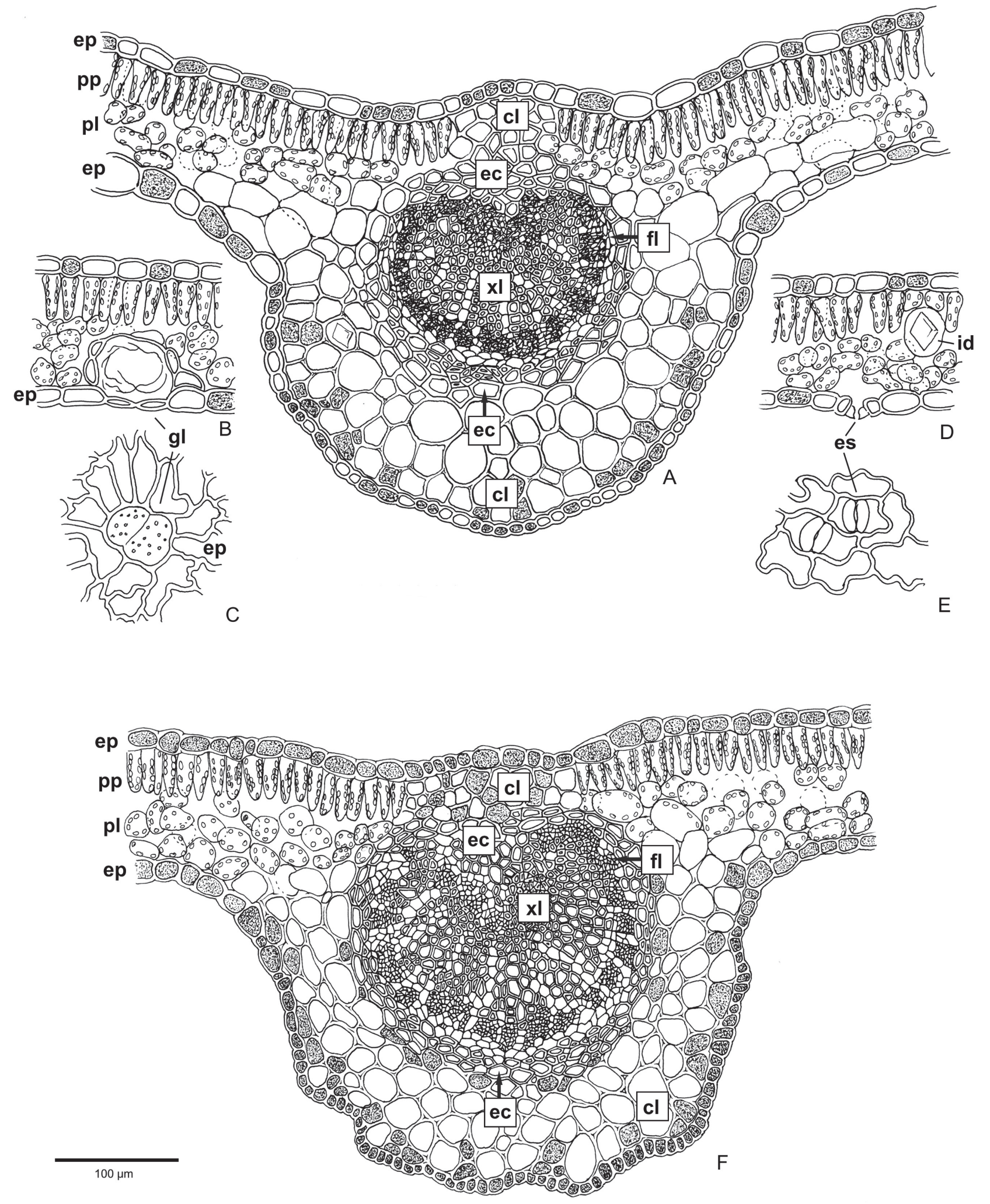

Figura 6. Anatomia do paracotilédone (A - E) e do eofilo (F) de Campomanesia xanthocarpa O. Berg. (Myrtaceae). A. Seção transversal da nervura central do paracotilédone; B. Seção transversal do limbo com glândula secretora; C. Glândula em seção paradêrmica; D. Seção transversal do limbo com estômato e idioblasto contendo cristal prismático; E. Seção paradérmica da face abaxial do paracotilédone; F. Seção transversal da nervura central do eofilo. (cl: colênquima; ec: esclerênquima; ep: epiderme; es: estômato; fl: floema; gl: glândula secretora; id: idioblasto; pl: parênquima lacunoso; pp: parênquima paliçádico; xl: xilema). 
A

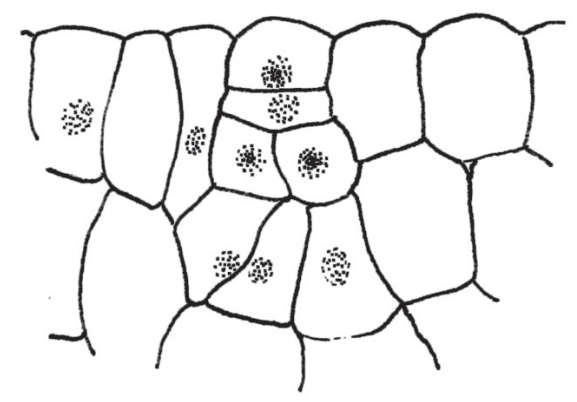

B

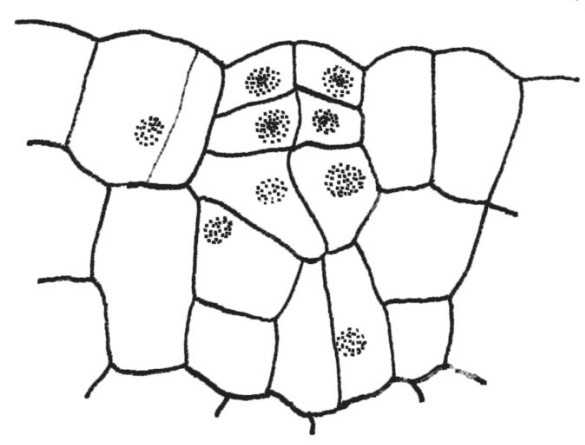

C

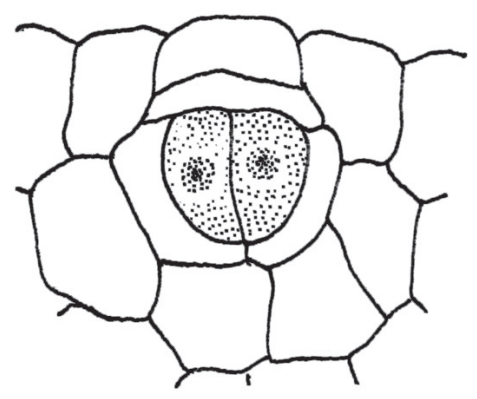

D

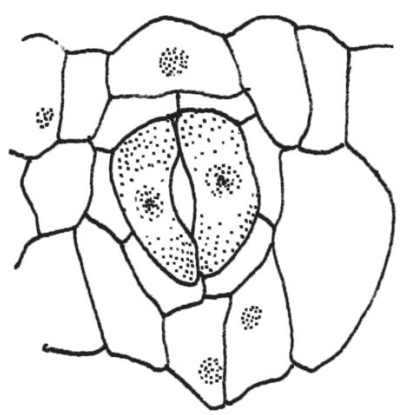

$E$

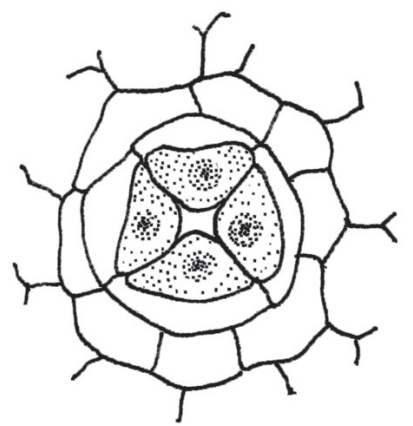

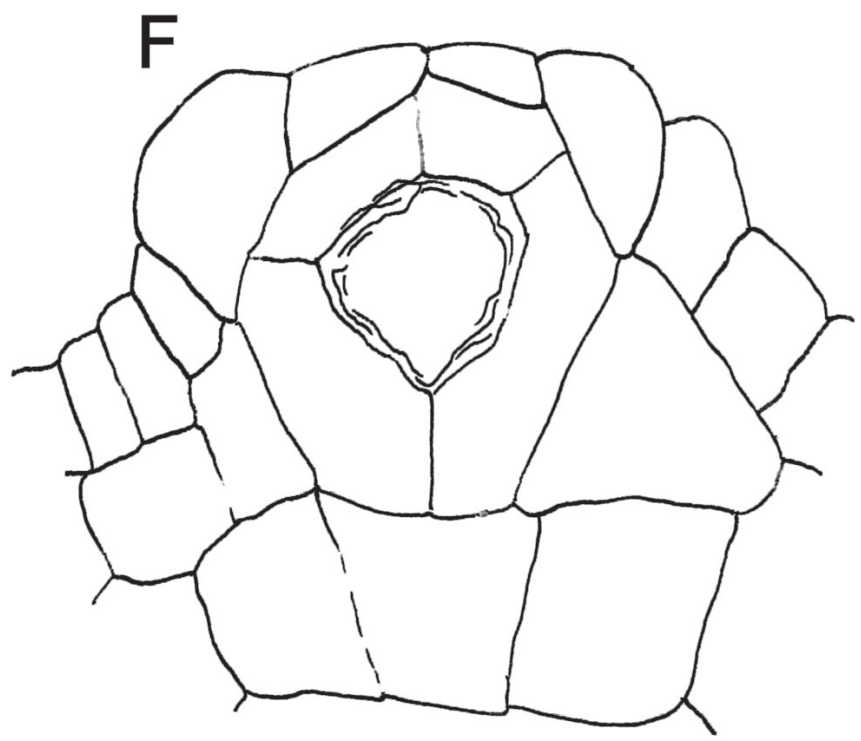

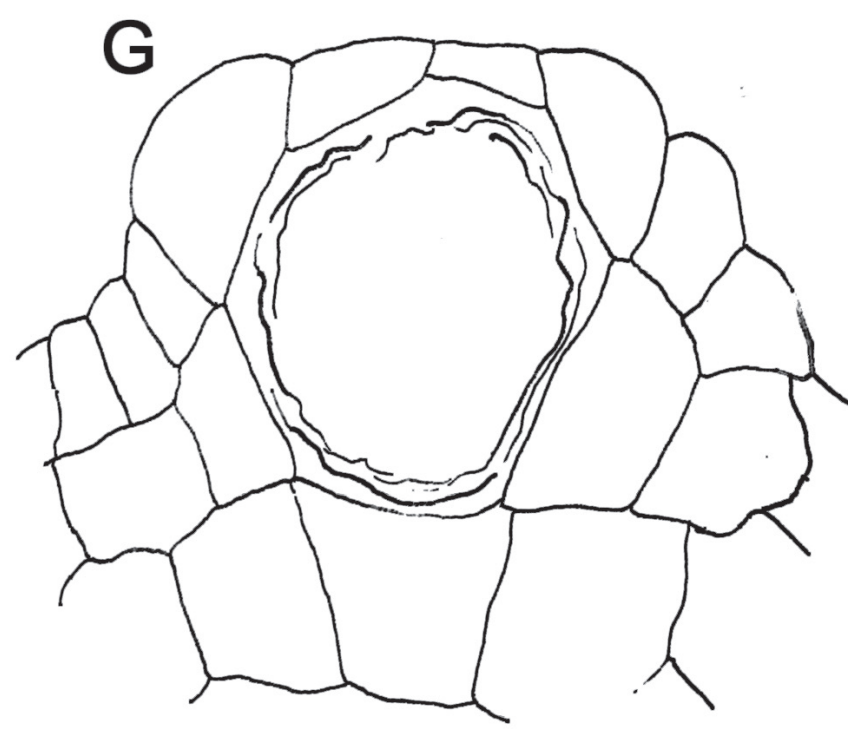

$25 \mu \mathrm{m}$

Figura 7. Ontogênese da glândula esquisolisígena de Campomanesia xanthocarpa O. Berg. (Myrtaceae). A-B. Fase inicial do desenvolvimento em dois planos transversais ortogonais. C-E. Fases subseqüentes com início da separação das células centrais (esquisogenia). F-G. Fases finais do desenvolvimento (lisigenia), com morte das células centrais. 
Constatou-se também a presença de células secretoras na epiderme, no córtex e na medula do hipocótilo, bem como no mesofilo e nas nervuras do paracotilédone e do eofilo, sendo mais abundantes nas primeiras camadas do córtex do hipocótilo, especialmente nas plântulas com sete dias. O conteúdo destas células ocorre de diferentes formas e, considerando o resultado do teste com sulfato ferroso, trata-se de compostos fenólicos.

Idioblastos com cristais prismáticos e drusas ocorrem na nervura central e no mesofilo do paracotilédone e do eofilo de C. xanthocarpa. Além disso, a epiderme apresenta tricomas tectores unicelulares no paracotilédone, no eofilo e no hipocótilo. Nestes tricomas ocorreu reação positiva com Sudam III, especialmente em sua base, indicando a presença de compostos lipídicos. A partir deste mesmo teste, pôde-se constatar ainda a ocorrência de uma cutícula delgada sobre a epiderme dos paracotilédones e dos eofilos.

\section{Discussão}

Algumas características morfológicas das plântulas de C. xanthocarpa, tais como a germinação epígea, o desenvolvimento fanerocotiledonar, e a presença de paracotilédones, são muito comuns em espécies heliófitas. Diversos autores ressaltam a função dos paracotilédones como órgãos fotossintetizantes, que possibilitam um rápido estabelecimento da plântula em ambientes com alta incidência de luz (Vogel 1980; Garwood 1996; Wright et al. 2000; Ressel et al. 2004). A combinação destes caracteres, segundo Ibarra-Manríquez et al. (2001), é muito comum entre as espécies que dependem da abertura de clareiras para seu estabelecimento.

Num sentido clássico, os cotilédones podem ser de três tipos: de reserva, haustorial e fotossintetizante (foliáceo). Porém, segundo Vogel (1980), em diversas espécies, este último tipo deve ser homólogo aos primeiros pares de folhas (eofilos), e não aos cotilédones propriamente ditos (haustoriais ou de reserva), que, em tais casos, foram abortados. $\mathrm{O}$ autor sugere que, para estas espécies, seja usado o termo paracotilédone. Diversas evidências levam a crer que, no caso de C. xanthocarpa, os cotilédones propriamente ditos podem ter sido perdidos durante o processo evolutivo, tendo os paracotilédones assumido sua posição.

Uma dessas evidências é a grande semelhança entre paracotilédone e eofilo, tanto do ponto de vista morfológico (forma, cor, textura, venação) quanto anatômico (epiderme, mesofilo, tipo de feixe vascular). Este fato sugere que os dois órgãos sejam homólogos, tal como nos casos citados por Vogel (1980). Além disso, o aspecto morfológico do hipocótilo e a presença abundante de amido neste órgão sugerem que este assume a função de manter o desenvolvimento inicial da plântula, tornando desnecessária a presença de cotilédones de reserva ou haustoriais.

Segundo Ducke (1969), em diversos membros de Myrtales, o hipocótilo tem aspecto robusto, sendo esta a região de reserva, em detrimento dos cotilédones, formando o tipo de embrião chamado “macropodial”. Para Landrum (1986), as estruturas embrionárias bem desenvolvidas do "complexo Campomanesia" - que inclui alguns gêneros da subtribo Myrtiinae - seriam adaptações ao aumento da quantidade de reserva no embrião. Nas espécies com este tipo de hipocótilo, os cotilédones são geralmente ausentes e, quando presentes, são vestigiais (escamiformes) no embrião, não se desenvolvendo nas plântulas (Vogel 1980; Beltrati \& Paoli 2003). Esse tipo de cotilédone ocorre em Blepharocalyx salicifolius (H.B.K.) Berg, considerando a descrição de S.S. Rego (dados não publicados). Os paracotilédones em C. xanthocarpa, ao contrário, se desenvolvem plenamente após a germinação. Observando o embrião dessas duas espécies, nota-se que estes são similares, sendo enquadrados no mesmo tipo (pimentóide) (Barroso 1999). Porém, as estruturas tidas como cotilédones no embrião se desenvolvem de forma distinta em cada uma das espécies. Esses detalhes demonstram que, no caso de Myrtaceae, em que a morfologia do embrião é usada na definição das subtribos (Landrum 1986), a observação do desenvolvimento pós-seminal pode ser bastante útil para uma caracterização mais precisa da variação morfológica dos grupos taxonômicos.

Diversas características morfoanatômicas observadas na plântula de C. xanthocarpa são típicas de Myrtaceae, tal como a estrutura da venação em arcos do paracotilédone e do eofilo, sendo o padrão mais comum nessa família (Landrum 1986). Da mesma forma, o cilindro vascular anfiflóico (Fig. 4A, D), tipo de arranjo em que o floema ocorre tanto externamente quanto internamente ao xilema (Cutter 1987), ocorre com frequência em Myrtaceae (Fahn 1982).

Quanto à origem do floema interno, Fahn (1982) relata que este pode diferenciar-se tanto do procâmbio, quanto de células de parênquima parcialmente diferenciadas. Este último caso é o que provavelmente ocorre em C. xanthocarpa, uma vez que nesta espécie o floema interno se forma a partir da divisão de células meristemáticas na periferia da medula, conforme descrito anteriormente.

Outra característica a ser destacada é a presença das glândulas e células secretoras na espécie estudada, que, segundo Metcalfe \& Chalk (1950) e Barroso et al. (1984), são frequentes em Myrtaceae. De acordo com Fahn (1982), as glândulas secretoras nos tecidos vegetais podem ser resultados da dissolução de células (lisígenas) ou de sua separação (esquizógena). Nos espaços lisígenos, células parcialmente desintegradas aparecem ao longo da periferia do espaço (Esau 1974). Segundo Esau (1974), lisigenia e esquizogenia podem ser combinadas na formação de espaços secretores. Fahn (1982) relata que alguns autores classificam a glândula de óleo das Myrtaceae como tendo origem lisígena, outros, porém, classificam-nas como esquizógenas. Em C. xanthocarpa, conforme já descrito, as glândulas se formam a partir da combinação dos dois processos. Ciccarelli et al. (2008) descrevem um padrão semelhante de desenvolvimento de glândulas em diversas partes da flor de Myrtus communis L., também pertencente à Myrtaceae. 
Quanto às células secretoras, estas são geralmente classificadas de acordo com as substâncias exsudadas (Fahn 1982). Em alguns casos, essas células podem conter a mistura de diferentes conteúdos, como no caso das folhas de Eucalyptus sp. (Myrtaceae), que contém óleos essenciais e compostos fenólicos (Castro \& Machado 2003). Em C. xanthocarpa, no entanto, predominam compostos fenólicos nas células secretoras.

Os tipos de conteúdo observados nas glândulas, tricomas e células secretoras em C. xanthocarpa são normalmente associados a mecanismos de interação entre plantas e animais, agindo como dissuasivo alimentar e reduzindo a herbivoria. Além disso, no caso em que as plantas estão sob estresse hídrico, os compostos fenólicos acumulados nos vacúolos, também garantem a manutenção do arcabouço celular e integridade dos tecidos (Castro \& Machado 2003).

\section{Conclusões}

A presença dos paracotilédones em Campomanesia xanthocarpa está relacionada ao seu rápido crescimento inicial, permitindo que a plântula não dependa por longo tempo das reservas contidas no embrião. $\mathrm{O}$ fato de a espécie ser heliófila pode estar relacionado à presença dos paracotilédones, embora as plântulas dessa espécie também se desenvolvam na sombra (observação de campo). Esta é uma característica que precisa ser amplamente investigada em espécies heliófilas e esciófilas.

Tanto as características morfológicas quanto anatômicas das plântulas de C. xanthocarpa são úteis para a identificação da espécie em estágio inicial de desenvolvimento. Como por exemplo, a morfologia do hipocótilo, a semelhança entre os paracotilédones e eofilos, a presença de glândulas esquizolisígenas, células secretoras e feixe vascular anfiflóico.

\section{Referências bibliográficas}

Barroso, G.M.; Guimarães, E.F.; Ichaso, C.L.F.; Costa, C.G.; Peixoto, A.L. \& Lima, H.C. 1984. Sistemática de Angiospermas do Brasil. v.2. Viçosa, UFV.

Barroso, G.M.; Morim, M.P.; Peixoto, A.L. \& Ichaso, C.L.F. 1999. Frutos e sementes: morfologia aplicada à sistemática de dicotiledôneas. Viçosa, UFV.

Beltrati, C.M. \& Paoli, A.A.S. 2003. Sementes. Pp. 399-424. In: Appezzatoda-Glória, B. \& Carmello-Guerreiro, S.M. Anatomia vegetal. Viçosa, UFV.

Berlyn, G.P. \& Miksche, J.P. 1976. Botanical microtechnique and cytochesmistry. Ames, The Iowa State University Press.

Castro, M.M. \& Machado, S.R. 2003. Células e tecidos secretores. Pp. 179-203. In: Appezzato-da Glória, B. \& Carmello-Guerreiro, S.M. Anatomia Vegetal. Viçosa, UFV.

Ciccarelli, D.; Garbari, F. \& Pagni, A.M. 2008. The flower of Myrtus communis (Myrtaceae): Secretory structures, unicellular papillae, and their ecological role. Flora 203: 85-93.

Cutter, E.G. 1987. Anatomia Vegetal: órgãos, experimento interpretações. v.2. São Paulo, Roca.

Ducke, J.A. 1969. Seeds, seedlings, systems and systematic. Annals of the Missouri Botanical Garden 55: 125-161.

Esau, K. 1974. Anatomia das plantas com sementes. São Paulo, Edgard Blücher Ltda.

Evert, F.F. 2007. Esau's Plant anatomy: meristems, cells, and tissues of the plant body: their structure, function, and development. $3^{\text {nd }}$ ed. New Jersey, John Wiley \& Sons.
Fahn, A. 1982. Plant anatomy. $3^{\text {nd }}$ ed. New York, Pergamon.

Garwood, N.C. 1996. Functional morphology of tropical tree seedlings. Pp. 59-129. In: Swaine, M.D. The ecology of tropical forest tree seedlings. Paris, Unesco/Parthenon Publishingp.

Hickey, L.J. 1979. A revised classification of the architecture of dicotyledonous leaves. Pp. 25-39. In: Metcalfe, C.R.; Chalk L. Anatomy of the dicotyledons: systematic anatomy of leaf and stem, with a brief history of the subject. Oxford, Clarendon Press.

Ibarra-Manríquez, G.; Ramos, M.M. \& Oyama, K. 2001. Seedling functional types in a lowland rain forest in Mexico. American Journal of Botany 88: 1801-1812.

Johansen, D.A. 1940. Plant microtechnique. New York, Mc Graw Hill Book.

Kuniyoshi, Y.S. 1983. Morfologia da semente e da germinação de 25 espécies arbóreas de uma floresta de araucária. Curitiba, UFPR.

Landrum, L.R. 1986. Campomanesia, Pimenta, Blepharocalyx, Legrandia, Acca, Myrrhinium and Luma (Myrtaceae). Flora Neotropica 45: 116-160.

Marques, M.C.M. \& Oliveira, P.E. 2005. Características reprodutivas das espécies vegetais da planície costeira. In: Marques, M.C.M. \& Brites, R.M. História Natural e conservação da Ilha do Mel. Curitiba, UFPR

Mcdowell, E.M. \& Trump, B. 1976. Histological fixatives for diagnostic light and electron microscopy. Archives of Pathology \& Laboratory Medicine 100: 405-414.

Metcalfe, C.R. \& Chalk, L. 1950. Anatomy of the Dicotyledons. v.1. Oxford, Clarendon Press.

Nakamura, A.T. \& Scatena, V.L. 2009. Desenvolvimento pós-seminal de espécies de Poaceae (Poales). Acta Botanica Brasilica 23: 212-222.

O’ Brien, T.P.; Feder, N. \& McCully, M.E. 1964. Polychromatic staining of plant cell walls by toluidine blue O. Protoplasma 59: 368-373.

Oliveira, D.M.T. 2001. Morfologia comparada de plântulas e plantas jovens de leguminosas arbóreas nativas: espécies de Phaseoleae, Sophoreae, Swartzieae e Tephrosieae. Revista Brasileira de Botânica 24: 85-97.

Oliveira, E.C. \& Pereira, T.S. 1987. Euphorbiaceae: morfologia da germinação de algumas espécies. Revista Brasileira de Sementes 9: 31-51.

Oliveira, E.C. 1993. Morfologia de Plântulas. Pp. 175-213. In: de Aguiar, L.B.; Pinã-Rodrigues, F.C.M. \& Figliolia, M.B. Sementes Florestais Tropicais. Brasília, ABRATES

Reitz, R.; Klein, R.M. \& Reis, A. 1983. Projeto Madeira do Rio Grande do Sul. Itajaí, SUDESUL.

Ressel, K.; Guilherme, F.A.G.; Schiavini, I. \& Oliveira, P.E. 2004. Ecologia morfofuncional de plântulas de espécies arbóreas da Estação Ecológica do Panga, Uberlândia, Minas Gerais. Revista Brasileira de Botânica 27: 311-323.

Sass, J.E. 1951. Botanical microtechnique. $2^{\text {nd }}$ ed. Ames, Iowa State College Press.

Souza, L.A. de. 2003. Morfologia e anatomia vegetal: célula, tecidos, órgãos e plântula. Ponta Grossa, UEPG.

Souza, L.A. de \& Oliveira, J.H.G. 2004. Morfologia e anatomia das plântulas de Tabebuia avellanedae Lor. Ex Griseb e T. chrysotricha (Mart. ex Dc.) Standl. (Bignoniaceae). Acta Scientiarum, Biological Sciences 26: 217-226.

Souza, V.C. \& Lorenzi, H. 2005. Botânica Sistemática: guia ilustrado para identificação das famílias da Angiospermas da flora brasileira, baseado em APGII. Nova Odessa, Instituto Plantarum.

Vallilo, M.I.; de Aguiar, O.T.; Fiumarelli, J.; Martins Junior, H.A.; Sassine, A. \& Bustillos, O.V. 2004. Identificação de terpenos no óleo dos frutos de Campomanesia adamantium (Cambessèdes) O. Berg. LandrumMyrtaceae. Arquivos do Instituto Biológico 71(supl.): 115.

Vogel, E.F. 1980. Seedlings of dicotyledons: structure, development, types: descriptions of 150 woody Malesian taxa. Wageningen, Centre for Publishing and Documentation.

Wright, I.J.; Clifford, H.T.; Kidson, R.; Reed, M.L.; Rice, B.L. \& Westoby, M. 2000. A survey of seed and seedling characters in 1744 Australian dicotyledon species: cross-species trait correlations and correlated trait-shifts within evolutionary lineages. Biological Journal of the Linnean Society of London 69: 521-547. 